\title{
An Employee Productivity of Selected Banks of India
}

\author{
Prof. Dr. N. M. Kanani, \\ Principal, Shri J. H. Bhalodia Women's College, Rajkot, India
}

\begin{abstract}
Commercial banks play an important role in the any country's economy by financing the requirements of trade, industry and agriculture with a greater degree of responsibility. Banks mop up deposits by drawing the community savings into the organized sector, which are then priorities laid down by the RBI in consonance with the fiscal policies of the GOI. Commercial banks can be described as a type of financial intermediary. Commercial banks provide a number of import financial and trading documents such as letters of credit, performance bonds, standby letters of credit, security underwriting commitments and various other types of balance sheet guarantees. They also take responsibility for safeguarding such documents and other valuables by safe deposit boxes .For the past three decades India's banking system has several outstanding achievements system to its credit. The most striking is its extensive reach. It is no longer confined to only metropolitans or cosmopolitans in India. In fact, Indian banking system has reached even to the remote corners of the country. Thus, Growing Indian economy is the result of effective Indian banking system amongst many other responsible internal and external factors, in which the role played by public commercial banks in the country is also a crucial one.
\end{abstract}

\section{INTRODUCTION}

Banking in India has its origin as early or Banking in India has its origin as early or Vedic period. It is believed that the transitions from many lending to banking must have occurred even before Manu, the great Hindu furriest, who has devoted a section of his work to deposit and advances and laid down rules relating to the rate of interest. During the mogul period, the indigenous banker played a very important role in lending money and financing foreign trade and commerce. During the days of the East India Company it was the turn of agency house to carry on the banking business. The General Bank of India was the first joint stock bank to be established in the year 1786. The other which followed was the Bank of Hindustan and Bengal Bank. The Bank of Hindustan is reported to have continued till 1906. While other two failed in the meantime. In the first half of the 19th century the East India Company established there banks, the bank of Bengal in 1809, the Bank of Bombay in 1840 and the Bank of Bombay in1843. These three banks also known as the Presidency banks were the independent units and functioned well. These three banks were amalgamated in 1920 and new bank, the Imperial Bank of India was established on 27th January, 1921. With the passing of the State Bank of India Act in 1955 the undertaking of the Imperial Bank of India was taken over by the newly constituted SBI. The Reserve Bank of India (RBI) which is the Central bank was established in April, 1935 by passing Reserve bank of India act 1935 . The Central office of RBI is in Mumbai and it controls all the other banks in the country. In the wake of Swadeshi Movement, number of banks with the Indian management were established in the country namely, Punjab National Bank Ltd., Bank of India Ltd., Bank of Baroda Ltd., Canara Bank Ltd. on 19th July 1969, 14 major banks of the country were nationalized and on 15th April 1980, 6more commercial private sector banks were taken over by the government. The first bank in India, though conservative, was established in 1786. From 1786 till today, the journey of Indian Banking System is very progressive.

At present scheduled banking structure has 26 public sector banks operating in India, 20 private sector banks, 40 foreign banks. Out of the 20 private sector banks, there are 13 old private sector banks and 7 new private sector banks.

In service sector, involvement of human element is of very high and this is application in banking service too. Attitude, interest, motivation, skills and knowledge, behavior, promptness, response to call etc. all are related to employees. These factors affect the individual and organizational performance. Hence, the concept of labor productivity is banking sector has great significance in present time. In present stiff competitive situation, it has become difficult to attract customers, retain and motivate them for further business. When employees give better performance then only the profitability of the banking unit will go high. Human resource is the most important resource of the organization. In a competitive and changing business environment, the need for highly skilled and dedicated manpower is felt who can give the best output. The firm that gets the advantage over other competitors through their talented and dedicated manpower can take the lead in the market. The contribution of employees on job is the most important factor for development and excellence in business. The performance of employees on different jobs in close coordination is needed for success of the unit.

\section{Objective}

Following two objects is considered in the present study

1. Employee Productivity Business per employee during research period of the selected public sector and selected private bankers.

2. Employee Productivity Profit per employee during research period of the selected public sector and selected private bankers

\section{RESEARCH METHODOLOGY}

The present study is concerned with the Indian banking system. For this five nationalized bank and five private banks have been selected for this study. The study is based on secondary data. The required data have been collected from the various issues of Banking Statistics, published by the Reserve Bank of India. To compare the performance of selected sector banks, ratio analysis as an accounting tool while F-Test ONE WAY ANOVA as statistical tools is used. The following ratios are analyzed to examine the performance of the study.

a) Business Per Employee

b) Profit Per Employee 


\section{A. Business Per Employee}

Banking is major and very important part of Service Sector in India. Therefore it is very necessary to study productivity of Banks. In simple words productivity means the ratio of output to input. Productivity is the quantitative relationship between what is produced and what is used in the process. In the service sector manpower and their higher efficiency is very important to achieve higher productivity. Employee's productivity means capacity of employees to produce maximum output with the use of minimum input and efforts. There are various benefits of high employee's productivity like, Employees feel satisfaction towards their job, their job involvement increases, it will develop sense of commitment and loyalty, employees get hike in salaries, organization get good profit and that will increase reputation of concerned organization in the Market.

\begin{tabular}{|c|c|c|c|c|c|c|c|c|}
\hline \multicolumn{8}{|c|}{$\begin{array}{c}\text { BUSINESS PER EMPLOYEE (RS. IN } \\
\text { MILLION) }\end{array}$} & \multirow[b]{2}{*}{ 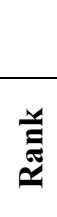 } \\
\hline $\begin{array}{c}\text { NAME OF } \\
\text { BANK }\end{array}$ & $\begin{array}{l}\text { 足 } \\
\stackrel{1}{1} \\
\stackrel{\sim}{\circ}\end{array}$ & 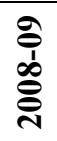 & 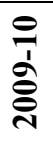 & 공 & $\stackrel{\text { I }}{\text { I }}$ & 承 & $\stackrel{ن}{\gtrless}$ & \\
\hline SBI & $\tilde{n}$ & $\stackrel{+}{i}$ & $\dot{7}$ & $\begin{array}{l}\infty \\
i \\
i\end{array}$ & $\stackrel{\Gamma}{\infty}$ & $\frac{a}{n}$ & $\hat{n}$ & $\infty$ \\
\hline PNB & $\bar{n}$ & $\begin{array}{l}n \\
0 \\
0\end{array}$ & $\stackrel{?}{2}$ & $\stackrel{n}{\varrho}$ & $\stackrel{0}{=}$ & $\frac{n}{\gamma}$ & $\hat{\text { iे }}$ & $\pi$ \\
\hline $\mathrm{BOB}$ & gे & $\overrightarrow{\tilde{a}}$ & $\stackrel{8}{0}$ & $\underset{n}{0}$ & $\widetilde{\sigma}$ & के & $\stackrel{+}{=}$ & 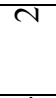 \\
\hline BOI & 6 & $\begin{array}{l}\infty \\
\stackrel{\infty}{\infty} \\
\infty\end{array}$ & 8 & $\stackrel{\mathrm{I}}{ }$ & $\underline{\underline{n}}$ & $\frac{m}{n}$ & $\hat{0}$ & + \\
\hline $\begin{array}{l}\text { UNION } \\
\text { BANK }\end{array}$ & 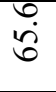 & $\vec{\infty}$ & $\stackrel{\nabla}{\infty}$ & $\widehat{\widetilde{I}}$ & 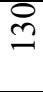 & 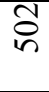 & $\bar{\sigma}$ & $n$ \\
\hline ICICI & $\stackrel{0}{=}$ & $\stackrel{0}{\simeq}$ & 8 & fo & त्र & $\stackrel{0}{2}$ & $\stackrel{m}{ \pm}$ & - \\
\hline HDFC & भे & iे & $\begin{array}{l}n \\
n \\
n\end{array}$ & $\overrightarrow{8}$ & oे & $\frac{9}{2}$ & $\begin{array}{l}\text { aे } \\
\text { in }\end{array}$ & $a$ \\
\hline AXIS & वें & $\begin{array}{l}n \\
\vdots \\
0\end{array}$ & \pm & 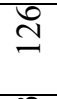 & $\stackrel{\jmath}{\beth}$ & in & $\cong$ & $m$ \\
\hline KOTAK & लm & लें & in & חై & ח̊ & $\begin{array}{l}3 \\
\grave{n}\end{array}$ & 章 & $\stackrel{0}{0}$ \\
\hline
\end{tabular}

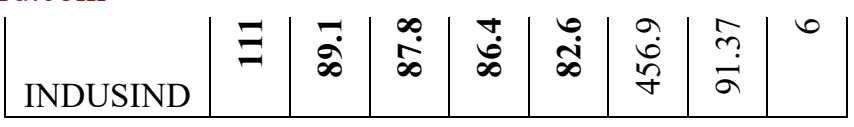

\section{Analysis for calculated ratio for selected banks}

Highest business per employee is generated by ICICI BANK which is 143.24 million Rs. which is followed by BOB with Rs. 113.69 Million, five Banks out of ten is having more than 100 million Rs. Business per employee during research period. HDFC and KOTAK MAHINDRA Bank is having lowest Business which is nearer to 50 Million Rs. during Research period.

\section{Graphical Analysis}

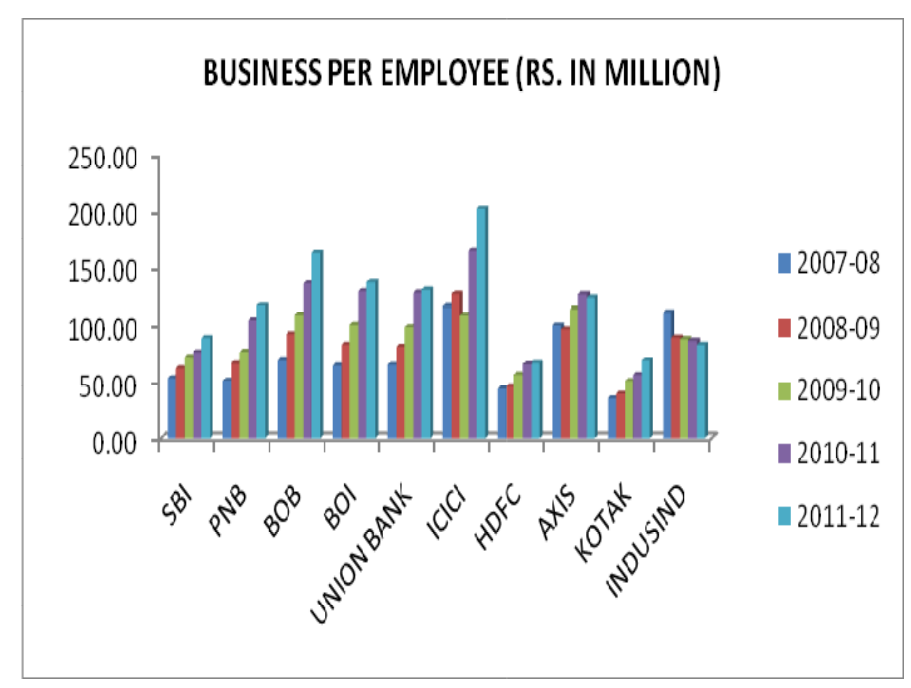

By observation of the graph of selected banks it shows that out of ten Banks five banks is having average business above 100 million Rs. while only HDFC and KOTAK Bank shows lowest Business during research period

\section{Statistical Analysis}

$\mathrm{H}_{0}$ :All the selected Banks have equal Business per employee in Million Rs.

$\mathrm{H}_{1}$ : All the selected Banks have unequal Business per employee in Million Rs.

Table 5.10

"F"-Test One Way ANOVA for Business Per Employee in Million Rs.

\begin{tabular}{|c|c|c|c|c|c|}
\hline $\begin{array}{l}\text { Source of } \\
\text { Variation }\end{array}$ & Sum of Square & $\begin{array}{l}\text { Degree of } \\
\text { Freedom }\end{array}$ & $\begin{array}{l}\text { Mean Sum of } \\
\text { Square }\end{array}$ & $\mathbf{F}_{\mathbf{c}}$ & $\mathbf{F}_{\mathbf{t}}$ \\
\hline B.S.S. & 36386.05683 & 9 & 4042.895 & \multirow{3}{*}{6.669631} & \multirow{3}{*}{2.124029} \\
\hline W.S.S. & 24246.59168 & 40 & 606.1648 & & \\
\hline T.S.S. & 60632.64851 & 49 & & & \\
\hline
\end{tabular}

From the "F" test one way ANOVA Table as calculated above it shows that Calculated value of $F_{c}=6.669631$ while tabular value of $F_{t}=2.124029$ which show that calculated value $F_{c}$ is greater than tabular value $F_{t} F_{c}>F_{t}$. Hence Null Hypothesis is rejected and Alternative Hypothesis is accepted that Business per employee in million Rs. Is different for selected Banks. 


\section{Profit Per Employee}

As a gauge of personnel productivity, this indicator simply measures the amount of profit generated per employee. The www.ijtsrd.com

higher the profit figure the better. Here again, labor-intensive businesses (ex. mass market retailers) will be less productive in this metric than a high-tech, high product-value manufacturer.

\begin{tabular}{|c|c|c|c|c|c|c|c|c|}
\hline \multicolumn{9}{|c|}{ PROFIT PER EMPLOYEE (RS. IN CR.) } \\
\hline $\begin{array}{l}\text { BANK } \\
\text { NAME }\end{array}$ & 2007-08 & 2008-09 & 2009-10 & 2010-11 & 2011-12 & TOTAL & AVG. & RANK \\
\hline SBI & 0.04 & 0.04 & 0.05 & 0.03 & 0.05 & 0.22 & 0.04 & 10 \\
\hline PNB & 0.04 & 0.06 & 0.07 & 0.08 & 0.08 & 0.33 & 0.07 & 4 \\
\hline BOB & 0.04 & 0.06 & 0.08 & 0.11 & 0.12 & 0.41 & 0.08 & 3 \\
\hline BOI & 0.05 & 0.07 & 0.04 & 0.06 & 0.06 & 0.3 & 0.06 & 7 \\
\hline $\begin{array}{l}\text { UNION } \\
\text { BANK }\end{array}$ & 0.05 & 0.06 & 0.07 & 0.08 & 0.06 & 0.31 & 0.06 & 7 \\
\hline ICICI & 0.1 & 0.11 & 0.11 & 0.19 & 0.26 & 0.77 & 0.15 & 1 \\
\hline HDFC & 0.04 & 0.04 & 0.06 & 0.07 & 0.08 & 0.29 & 0.06 & 7 \\
\hline AXIS & 0.07 & 0.09 & 0.12 & 0.13 & 0.13 & 0.54 & 0.11 & 2 \\
\hline КОТАK & 0.03 & 0.03 & 0.06 & 0.08 & 0.1 & 0.31 & 0.06 & 7 \\
\hline INDUSIND & 0.03 & 0.03 & 0.07 & 0.08 & 0.09 & 0.29 & 0.06 & 7 \\
\hline
\end{tabular}

\section{Analysis for calculated ratio for selected banks}

From the above table it shows that highest profit per employee shown by ICICI Bank which is followed by AXIS Bank and two nationalized Bank PNB AND BOB while BOI, UNION BANK, HDFC BANK, KOTAK MAHINDRA and INDUSIND is having equal average profit per employee during research period while SBI shows low average during the research period.

\section{Graphical Analysis}

\section{PROFIT PER EMPLOYEE (RS. IN CR.)}

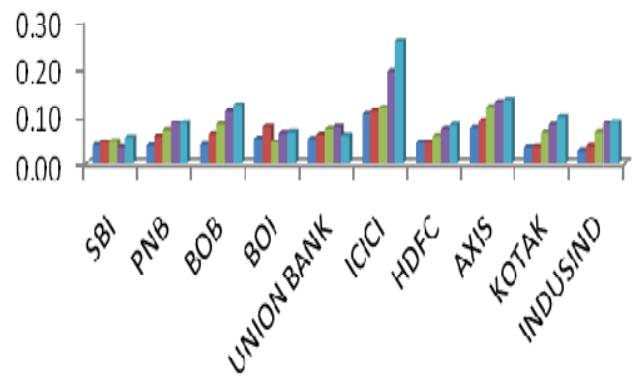

2007.08

2008-09

2009-10

2010-11

2011-12

From the above graph it shows that ICICI Bank is showing high profit per employee during research period in compare to other bankers. AXIS , BOB and PNB followed to ICICI while remaining bankers are showing average equal profit during research period.

\section{Statistical Analysis}

$\mathrm{H}_{0}$ :All the selected Banks have equal Profit Per Employee in Million Rs.
$\mathrm{H}_{1}$ : All the selected Banks have unequal Profit Per Employee in Million Rs.

\begin{tabular}{|c|c|c|c|c|c|}
\hline \multirow{2}{*}{ 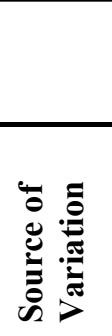 } & \multicolumn{5}{|c|}{$\begin{array}{l}\text { Table 5.10 } \\
\text { "F"-Test One Way ANOVA for Profit Per } \\
\text { Employee in Cr. Rs. }\end{array}$} \\
\hline & 泀 & 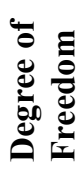 & 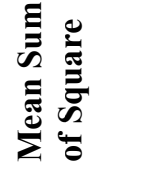 & $\mathbf{F}_{\mathbf{c}}$ & $F_{t}$ \\
\hline B.S.S. & 0.048366 & 9 & 0.005374 & \multirow[t]{3}{*}{6.070894} & \multirow[t]{3}{*}{2.124029} \\
\hline W.S.S. & 0.035409 & 40 & 0.000885 & & \\
\hline T.S.S. & 0.083775 & 49 & & & \\
\hline
\end{tabular}

From the "F" test one way ANOVA Table as calculated above it shows that Calculated value of $\mathrm{F}_{\mathrm{c}}=6.070894$ while tabular value of $F_{t}=2.124029$ which show that calculated value $F_{c}$ is greater than tabular value $F_{t} F_{c}>F_{t}$. Hence Null Hypothesis is rejected and Alternative Hypothesis is accepted that Profit per employee in Cr. Rs. Is different for selected Banks.

\section{CONCLUSION}

Productivity is a vital indicator of economic performance of an economic system. Productivity is not an end in itself. In fact, it is a mechanism for improving the material quality of life. Productivity is fundamental to progress throughout the world. It is at the heart of economic growth and development, improvements in standards of living and quality of life. 


\section{www.ijtsrd.com}

\section{References}

[1] Kopleman, Richard E., Managing Productivity Organizations. McGraw Hill Book Company, New Delhi, 1986, p.3.

[2] Nag. A. K and Shivaswamy. K (1990), Foreign Banks in India - Recent Performance, Reserve Bank of India Occasional Papers, Vol. 11, No. 4, December, pp 297328.

[3] Pal. K and Goyal. P (2008), Productivity-based Comparative Analysis of Public, Private and Foreign
Banks, The Indian Journal of Commerce, Vol.61, No.3, pp 22-35.

[4] Profitability of Banks: A Study conducted by CRISIL, 2002.

[5] Prasad. K.V.N.(2012), Evaluating Performance of Public and Private Sector Banks through CAMEL Model, Asian Journal of Research in Banking and Finance,Vol.2,No.3, March. 